\title{
Forts of the Wakatobi Islands in Southeast Sulawesi ${ }^{1}$
}

\author{
Nani Somba
}

\section{Introduction}

The Wakatobi Islands are part of a larger archipelago known as the Tukang Besi Islands, located in the Flores Sea to the southeast of Buton Island (Figure 1.1 this volume). Wakatobi is an acronym of the four main islands that make up the group, namely Wa (Wangi-Wangi), Ka (Kaledupa), To (Tomia) and Bi (Binongko) (Wikipedia 2020). This name was first used in 1959, when the Wakatobi region was administratively separated from the Buton Regency.

The islands contain a rich cultural heritage record, but to date there is no management strategy to protect and enhance the cultural resources of Wakatobi. This study aims to provide an inventory of the forts present on the islands to assist in the development of a management strategy. The methods used include a surface survey, observation of the cultural relics and interviewing residents with knowledge of the issues under investigation.

The Wakatobi forts cannot be appreciated in isolation from the kingdom of Buton, which is recognised as one of the key maritime kingdoms instrumental in the acclaimed spice trade from the Maluku Islands during the sixteenth and seventeenth centuries (Andaya 1991). The Wakatobi forts had their origins during this period when they were developed as part of Buton's four buffer zone (Barata pata mplena) system of governance. The Barata pata mplena included the locations of Kolensusu (based on the Buton mainland), Kaledupa (Wakatobi Islands), Muna and Tiworo (both on Muna Island). This was a multilayered defence system designed to protect the Buton kingdom from foreign, especially European, intervention. Evidence from two of the four Wakatobi forts, Fort Kaledupa and Fort Liya will be presented in this paper. They were developed as part of the defence system of the wider kingdom with its large and imposing central fort (Wolio) overlooking the anchorage at Bau-Bau, the centre of the Buton Sultanate. One of these fortified sites, Fort Liya, has been subsequently developed as a tourist attraction, so its investigation was a priority to provide information and advice on tourism and conservation strategies to the local government. 


\section{The history and geography of the Wakatobi Islands}

There are two origin stories about the names of the Tukang Besi Islands. The more prosaic version is that the phrase derives from the practice of blacksmithing (tukang besi) which was a common practice by the people of the islands. During a visit to Binongko Island, a Dutch man named Hoger saw a lot of people busy making tools from iron, and so he called the area Toekang Besi Eilanden ('Blacksmith Island', see Hamid 2007:36). However, another story assigns the name to Tulukabesi, the king of Hitu (in Maluku), who took up arms to oppose the Netherlands East India Company (Vereenigde Oostindische Compagnie, or VOC). According to the story, armed resistance was provoked by the actions of the VOC in preventing the islanders from felling clove, nutmeg and mace trees as part of imposing its monopoly on the Moluccan spice trade (Abubakar 1999a). The VOC captured Tulukabesi along with about 300 of his followers and exiled them to the eastern part of Buton Island. This did not quell Tulukabesi's hatred for the Dutch, and he resumed his resistance on the nearby island of Wangi-Wangi. The rebellion reportedly spread to the other islands including Kaledupa, Tomia, and Binongko, and so the region was named the Tukang Besi Islands after Tulukabesi (Abubakar 1999a, 1999b).

Before the Wakatobi Islands were controlled by the kingdom of Buton, and prior to the arrival of the Dutch in the sixteenth century, the area was reportedly named Liwuto Pataanguna, which means 'Four Islands' in the Wolio language of Buton. Another popular name was Liwuto Pasi, meaning 'Coral Islands'. The tropical islands stretch between $5.00^{\circ}$ and $6.25^{\circ} \mathrm{S}$ north to south, and $123.34^{\circ}$ and $124.64^{\circ} \mathrm{E}$ west to east. Wangi-Wangi Island covers an area of $448 \mathrm{~km}^{2}$, Kaledupa Island $104 \mathrm{~km}^{2}$, Tomia Island $115 \mathrm{~km}^{2}$ and Binongko Island $156 \mathrm{~km}^{2}$. The total area has a combined land mass of $823 \mathrm{~km}^{2}$ (Rosmawati 2018).

Structurally the Wakatobi Islands comprise a limestone massif, geologically uplifted from the ocean floor. The extensive lowlands or coastal plain are characterised by rocky, porous alkaline soils. Cultivation of any kind is difficult on these barren and unvegetated chalklands where any surface water seeps deep into the ground. Karstic geologies containing underground stores of freshwater have been discovered in each of the four main islands and have long provided a source of brackish water for the residents. The high salt concentration, however, makes the water unhealthy for consumption, particularly during high tides when the sea level rises above the level of the karstic caves. These days there is a regular trade in bottled water (galon) for drinking while shallow wells are still widely used for washing and bathing.

The islands also have talc-white limestone uplands. The highest plateau, Tindoi Hill, located on Wangi-Wangi Island, rises more than $770 \mathrm{~m}$ above sea level. Mori Hill on Tomia Island is more than $250 \mathrm{~m}$ high, Taipabu Hill in Binongko Island is barely $22 \mathrm{~m}$ high, while the highest plateau on Kaledupa Island is just $230 \mathrm{~m}$ high (Hamid 2007:41). These rock formations enclose accumulations of soil that are sometimes used for agricultural purposes. This occurs particularly on Kaledupa Island, which is more fertile than the other three and produces annual crops of maize and secondary food crops.

In some coastal areas, mangrove forest adds greenery to the otherwise bleached landscape. However, much of the coastline consists of steep, wave-cut cliffs of limestone. Coral reefs around the islands form a narrow strip of shallow water that is protected from the pounding waves of the surrounding seas. The Wakatobi Islands lie at the confluence of the Banda Sea and the Buru Sea in the northeast, the Flores Sea in the southwest and the Buton Sea in the east. This latter has the least forceful waves and the coastal settlement of Ouw in the west is well known and used as a safe harbour for mooring boats. 
The Wakatobi seafloor topography includes 25 coral reefs with a total circumference of some $600 \mathrm{~km}$. The reefs include coral beaches, barrier reefs and atolls. They are scattered across an area which is now included in the Wakatobi Islands National (Marine) Park (TNKW). The island region receives a double monsoon, including heavy rains from the west during November to February, and strong winds from the southeast during the dry period July-September. The region is affected by seasonal currents and ocean swells that track the monsoons (Nontji 1987:68), and at times these conditions make seafaring and boat travel a hazardous activity. Given its position and the abundance of reefs, the area also stands out as habitat for abundant fish of many species. Its fisheries production and potential attract local fishing communities from the Wakatobi Islands, as well as commercial interests from other areas of southern Sulawesi.

Written sources are limited on the origins and dates of arrival of the people who now occupy the Wakatobi Islands. Linguistically, the Tukang Besi language is closely related to the Bonerate language, spoken on the Bonerate Islands to the southeast (Donohue 1999), and these two languages belong to the Muna-Buton cluster of Southeast Sulawesi languages (Joshua Project 2020). However, the Wakatobi Islanders are also fluent in Wolio, the language of Buton, which was the unifying language of the areas formerly under Buton's sway (Hamid 2007:59-63). In addition, many people place the Butonese title ode before their name (' $\mathrm{La} O \mathrm{Ode}$ ' for fathers and 'Wa Ode' for mothers). These sorts of influences from Buton Island are to be expected, as the Wakatobi Islanders were allies of the Buton Sultanate over hundreds of years and participated in a maritime trade network that extended over much of eastern Indonesia as far as the Papuan coast.

The use of ode as a title can be traced in Buton to its fourth sultan, La Elangi Dayanu Ikhsanuddin (1578-1615). He initiated Buton's prevailing system of social stratification by recognising upper and lower classes that cut across Buton's four societal groups. The upper class consisted of the kaomu, descendants of the first king (Wa Kaka), and the walaka (nobles). Ode was one of the titles used by members of the upper class to signify their status.

Most of the upper class initially lived within the fortified walls of the palace centre of Wolio but others, such as the community leaders in the rural settlements (kadie), lived outside the palace centre. The koamu and walaka together ruled the lower class, which included the papara and batua. Whereas the papara lived in rural communities and enjoyed considerable freedom, the role of the batua was to serve their designated master, both within the sultanate centres and the kadie villages.

As the population developed, there was a gradual increase in the number of high-status households who lived outside the palace centre. One area where they became numerous was in the islands of Wakatobi. Those who lived in the outlying districts had to travel to the palace centre at least once a year, specifically to attend a general meeting that coincided with the inaugural feast of Murtabat Tujuh (the 'Seven Grades'). If they failed to attend this event, their social status would be downgraded to an intermediate class, either analalaki (if they had been kaomu) or limbo (if they had been walaka). This policy was designed to maintain relationships across the upper class group whether they lived within the centre of government or in the regions.

This method of government evolved into the system of four barata established during the first half of the seventeenth century. The barata were autonomous regions that had their own governing structure but were required to submit to Buton's overall territorial control. One of these barata, Kaledupa, was located in the Wakatobi Islands. 


\section{Fort Kaledupa}

Fort Kaledupa is located in South Olio village, Kaledupa subdistrict, on the island of Kaledupa. To the east of the fortress, there is a coastal plain with settlements and the foreshore of the Banda Sea, while in the west there are steep hills. The fort's position on a limestone hill circumscribed by steep cliffs, and its vantage point overlooking the sea, were ideal for guarding against a seaborne attack. Around the site, both within and outside the fortress, there are houses and food gardens generally planted with cassava, cashew nuts, coconuts and other tree crops.

Fort Kaledupa is quadrangular stone structure with a north-south orientation some $400 \mathrm{~m}$ long and $50 \mathrm{~m}$ wide. The walls are curved following the contours of the ground surface and so the sides are not symmetrical. There are two main gates positioned at the north and the south respectively. Above the main gates are two wooden frameworks with gabled roofs that serve as guard posts (Figures 9.1 and 9.2). On the northwest side of the main entrance, there is a stone bastion-like structure. It consists of $2 \mathrm{~m}$ thick walls that extend outward $3 \mathrm{~m}$ to define a doorway $4 \mathrm{~m}$ wide. The walls also include three smaller gateways on both sides, spaced more or less evenly apart. The dimensions of these smaller gates are 1-1.5 m wide, and all were crowned historically with a stone structure.

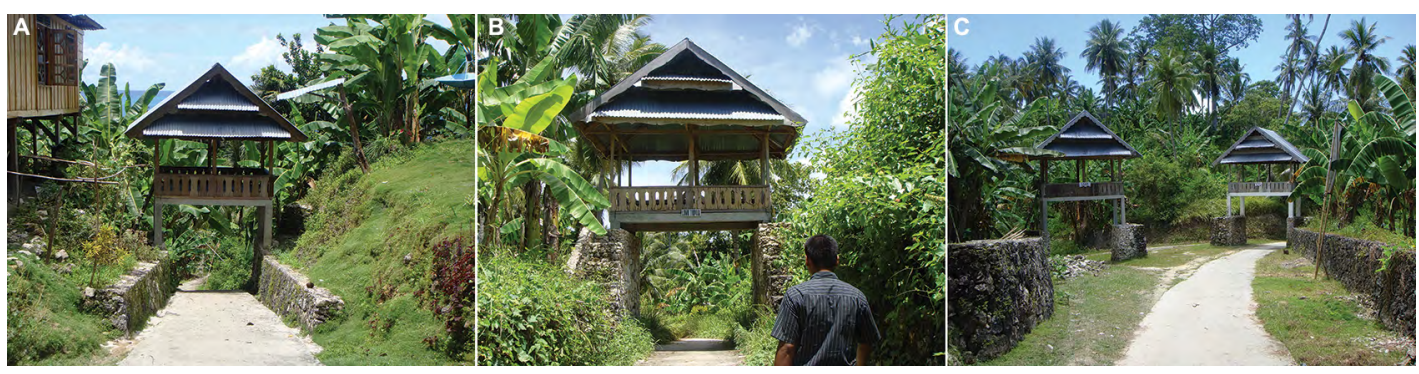

\section{Figure 9.1. Fort Kaledupa.}

A. South Gate; B. East Gate; C. North Gate.

Source: Photo courtesy of Nani Somba.

The enclosing walls of Fort Kaledupa are made of dry stacked and finished limestone blocks that are likely to have been quarried from the surrounding landscape and assembled onsite. The size of the stone elements is not uniform, but they are neatly and securely arranged. The walls range from 1 to $2.5 \mathrm{~m}$ thick, and from 1.5 to $3 \mathrm{~m}$ high. Some parts of Fort Kaledupa are now experiencing considerable damage from weathering and pilfering of stone materials for subsequent repurposing by local farmers. On the east side of the fort attached to the villagers' houses, for example, most of the stonework has been removed over time to build houses, roads and garden fences. Efforts to conserve and protect the fortification have been made by the local government at key sections of the structure, but the site remains vulnerable due to limited conservation resources. Two cannons from Fort Kaledupa are currently stored at the local police station. According to local beliefs, the cannons were used as defensive weaponry when the fort was in active use: one cannon was placed on top of each gate. This suggests that there may have originally been a larger number of cannons but their whereabouts today remains unknown.

During the early seventeenth century, the ruler of Buton submitted to the imperial ambitions of the Makassarese kingdoms of Goa and Tallo in South Sulawesi and converted to Islam, along with the court and kingdom. Evidence of Islamisation in the Wakatobi Islands comes from an old mosque in Kaledupa, the so-called Kaledupa Palace Mosque, located at the west side of the fort near the main north gate (Figure 9.2). The mosque has been subject to restoration work a number of times, but traces of its antiquity are still visible. These traces include its square 
shape, $14 \times 14 \mathrm{~m}$, and the use of limestone blocks for the foundation and supporting walls. The blocks have been stacked together to produce walls $80-95 \mathrm{~cm}$ thick and $1.5-2 \mathrm{~m}$ high, on which wooden pillars form the framework for the mosque itself.

The front porch has a flight of five limestone steps in the shape of a gate. Each of the four sides of the mosque has a wooden lattice vent to facilitate airflow. The mibrab and wooden pulpit are carved with a leaf design (Figure 9.2), and there is a water vessel at the front gate for the ablutions prior to prayer. At the centre of the mosque, there are four wooden pillars once used to support the mosque's superstructure. The roof is two-tiered in a style consistent with local architectural traditions and includes a platform right at the top where a mosque official could stand and call the parishioners to prayer. The spire is decorated with a carved wooden conical crown, and there is a large wooden buffalo-skin drum that was used historically to call the faithful. Overall, the shape of the Old Kaledupa Mosque resembles that of Buton's royal mosque, located in Wolio (Bau-Bau).
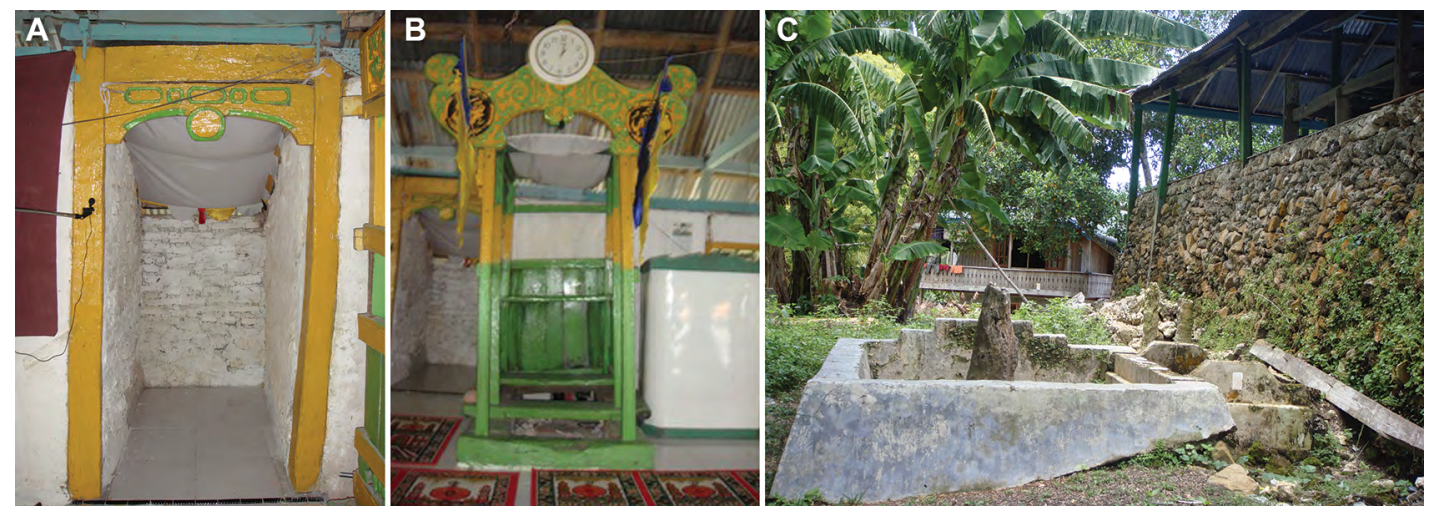

Figure 9.2. Kaledupa Mosque.

A. Pulpit; B. Mihrab; C. Ancient grave behind mosque.

Source: Photos courtesy of Nani Somba.

On the south and west sides of the fort, there are some abandoned and badly deteriorated ancient graves. Inside the fort, there are around 20 ancient graves scattered around the old mosque (Figure 9.2), which are believed to be the resting places of past nobles and their families. The gravestones are simple in shape, consisting of sepulchre and club-like headstones carved from limestone. This graveyard and the other parts of the fort are still in use by local people as their cemetery.

\section{Fort Liya}

Fort Liya is located on Wangi-Wangi Island in a strategic location on a hilltop surrounded by steep cliffs. It enjoys panoramic views over the plains, and to the coast and seas beyond. This elevated location enabled the early detection of potential enemies whether advancing overland or from the sea. The fort is another quadrangular wall structure some $500 \mathrm{~m}$ long by $80 \mathrm{~m}$ and oriented east to west. The walls along the east-west alignment are straight, whereas the north and south walls wind and curve following the contours on the ground and creating an asymmetrical walled structure. There are two main gates on the eastern and western sides, which extend out like a bastion. These walls forming the bastions are $6 \mathrm{~m}$ thick and spaced $7 \mathrm{~m}$ apart. They frame the $2 \mathrm{~m}$ wide entrance to the inner space. Like the Kaledupa fort, the east and the west walls both have three gates, 1-1.5 m wide, and were formerly crowned by stone structures. Metalroofed, wooden guard post structures frame the main entrances and are evidently later additions (Figure 9.3). 


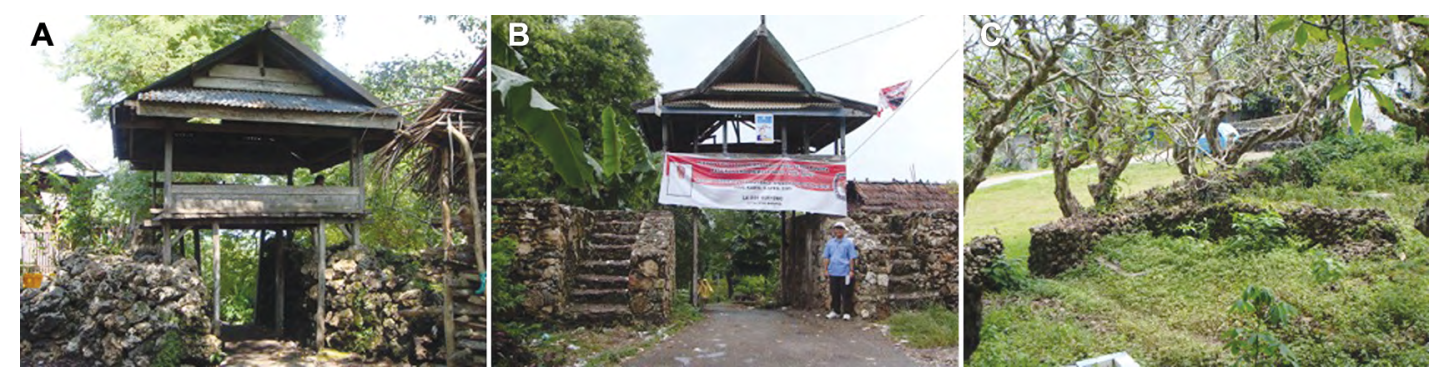

Figure 9.3. Fort Liya.

A. South Gate; B. West Gate; C. Bulkheads inside fort.

Source: Photos courtesy of Nani Somba.

The walls of Fort Liya closely resemble the construction of the Kaledupa fortification on the neighbouring island. Extensive use is made of dry-fitted limestone blocks of varying size with average dimensions $1.5-2.5 \mathrm{~m}$ thick and $1.5-3 \mathrm{~m}$ high. The faced stones of the outer walls mask a central core of limestone rubble in the characteristic style of the wider region and are indicative of a structure built to defend against cannon attack. Most of the structure is badly damaged, the result of opportunistic plundering by local people for other purposes including house construction and garden walls. Much of the south wall has collapsed and is now overgrown with a tangle of trees and shrubs and climbing vines. However, the gate on the west side was restored by the local government in an earlier, short-lived phase of heritage conservation and remains in good condition.

Inside the fort, there is a stone wall about $1 \mathrm{~m}$ high (Figure 9.3), which is probably the bulkhead between spatial divisions for different functions. Alternatively, the partition may reflect a boundary between status groups within the ruling group. According to local historians, each gate originally had cannons placed on both sides inside the walls. Large cannons were said to guard the two main gates while smaller or medium-sized cannons were positioned at the other gates. In addition, according to a local informant, in historical memory many other places within the fort were defended with 'small bore' cannons along the perimeter. My Wangi-Wangi informant estimated that when the site was actively maintained as a fortified settlement, it featured as many as 32 cannons, including 16 positioned at the respective gates. However, these days there are just eight cannons remaining in the fort, some of which are damaged and badly rusted (see Figure 9.4).

Inside the fort, there are three monumental buildings, the old mosque (Figure 9.4), the baruga or traditional meeting house (Figure 9.4) and a traditional residential house built in the 1920s. The baruga is a rectangular structure located on an elevated field at the northern end of the fort. The large structure is $16 \mathrm{~m}$ long and $12 \mathrm{~m}$ wide, while the walls are $3.5-4 \mathrm{~m}$ tall and $0.7-1 \mathrm{~m}$ thick. On its north side is a huge banyan tree. According to local informants, the baruga field was formerly used as a training ground by soldiers attached to the fort, but given its significance as a ritual house, it is also likely to have been used for ceremonies or as a meeting place for deliberations, as is still customary among local residents. The now badly damaged traditional house is located near the south gate of Fort Liya. It is made of timber with solid square pillars. The front part of the house is an open space, while the back of the house contains separate bedrooms and a kitchen. 

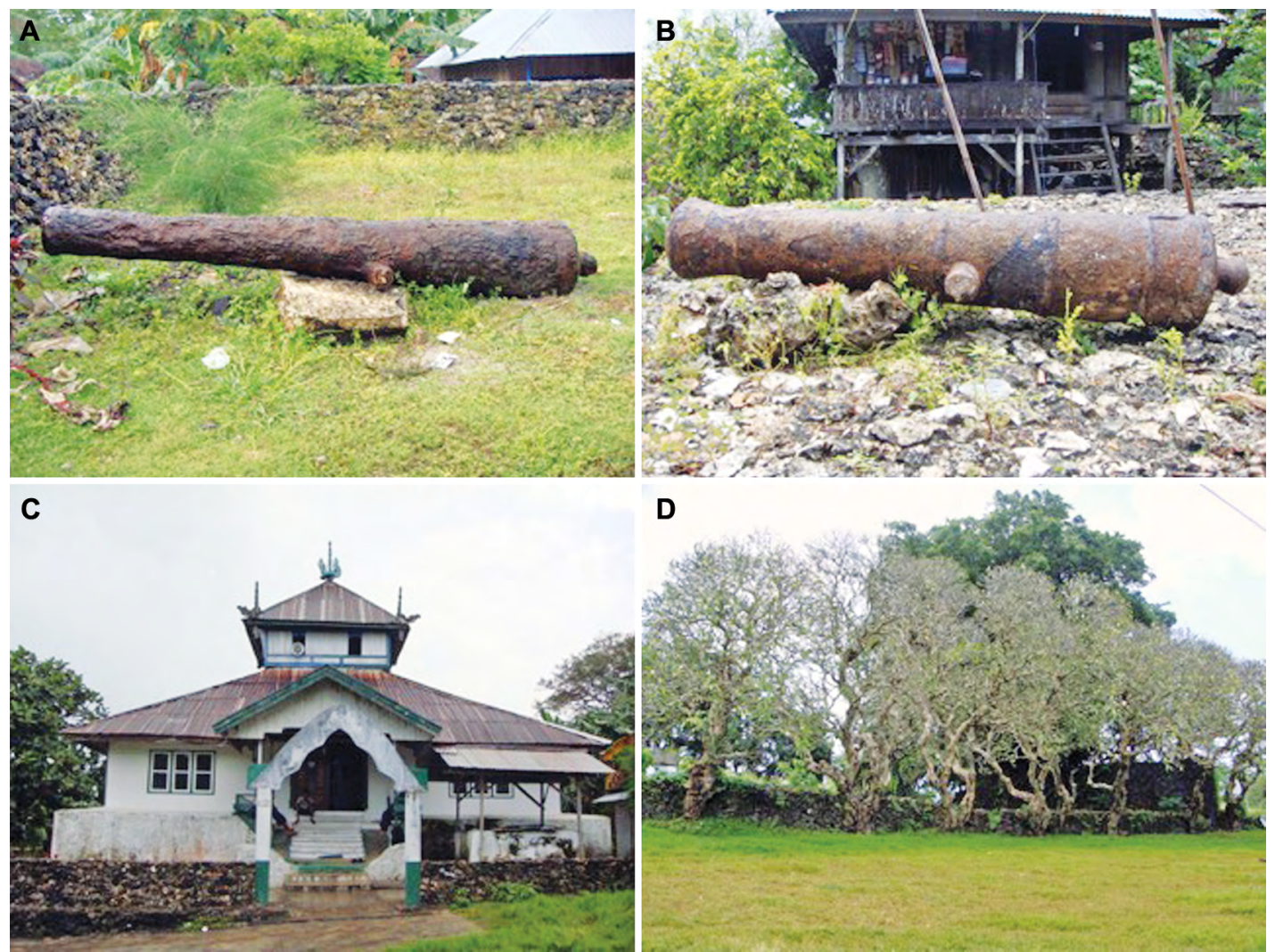

Figure 9.4. Fort Liya.

A and B. Cannons; C. Ancient mosque; D. Baruga and cemetery.

Source: Photos courtesy of Nani Somba.

Near the baruga is a cemetery with ancient graves, believed to commemorate the resting places of former nobles and their families. The gravestones are simple in shape, involving only sepulchre and club-like headstones made of limestone. The cemetery and other parts of the fort are still used by local people for burying family members with links to the site. The imported ceramic sherds recovered from the surface of the fort include Chinese (sixteenth to seventeenth centuries), Vietnamese and European wares. Some of the sherds are the vestiges leftover from treasure hunters who looted the area around the old cemetery looking for antiques. However, other sherds would appear to reflect a tradition, practised until today, of adorning gravestones with porcelain plates and bowls and other high-value porcelain and tradeware.

In addition to foreign ceramics, there are sherds of old pottery from utilitarian wares used in daily life. Another interesting discovery found among the surface scatters is a dense distribution of seashells, evidence that the locals have consumed marine shellfish for centuries.

On the southwest side of Fort Liya, there are several old hand-dug wells, both located inside and beyond the walls of the fort. According to several local informants, the wells have been used by local community members for centuries to provide for their freshwater needs. The well within the confines of the fortification highlights a critical source of potable water during times of warfare or assault on the fort. 


\section{Discussion}

The Kaledupa and Liya forts are well designed as defence posts. Their hilltop location is advantageous for monitoring and resisting the intentions of enemy troops and fending off armed attacks. Both forts also functioned as residential sites, and likely as centres of government during times of instability and threat, not only for local administration, such as it was, but also as outlying district representatives of the kingdom of Buton. These locations were also important in bringing Islamic governance to Wakatobi. Islamic cities in Indonesia were based on a model of palaces, mosques and other royal buildings clustered around the city square. Here the people, who lived for the most part beyond the city walls, had the opportunity to meet the sultan and courtiers of the palace. Built remains that echo this form of government were recorded on Fort Kaledupa and especially in Fort Liya. The survey of Fort Liya also produced evidence for longterm settlement outside of the walls in a pattern that is common throughout the region. During peaceful times people would live for the most part in their food gardens and tree crop plantations, only retreating into the safety of the forts during times of attack or when raiding parties were in the vicinity.

Today, the Wakatobi Islands are a maritime transit zone between the islands of western Nusa Tenggara and the southwestern and southeastern peninsulas of Sulawesi (Makassar and Buton respectively). The maritime trade routes from Seram Island and Buru Island (Maluku) to Timor and Bali (via Sumbawa) also passed through the waters of Bonerate Island and the Wakatobi Island groups. One particularly important period in the archipelago's maritime history covers the centuries of the spice trade, when cloves, nutmeg and mace were produced in large quantities only at Ternate and Tidore, off the coast of Halmahera, and on Banda Island in the middle of the Banda Sea. Long before the height of this spice trade in the seventeenth to eighteenth centuries, trading ships sailed from the spice islands in the east to the port cities in the western archipelago, and onward to China and the Mediterranean Sea. For instance, when the Chinese geographer Wang Ta-yuan visited Java in the 1340s, the local spice trade network had fallen under the hegemony of the Javanese kingdom of Majapahit The Wakatobi Islands, especially Kaledupa and Wangi-Wangi, were already important nodes in the Java Sea maritime trade zone (Reid 1992:2-4; Hamid 2007:73).

Hand in hand with legitimate maritime trading activity was the constant threat of pirates and slave traders, whose areas of operation covered the seaborne trading networks in and around the archipelago. The strategic trading position of Wakatobi made these islands a prime target for pirate groups and other maritime interests sustained by standover tactics and theft. They were also vulnerable to pirate attack due to their geographical isolation from major commercial empires in the eastern waters, such as Goa (southwest Sulawesi) and Buton. The most notorious pirate groups were based in Papua (seventeenth-eighteenth centuries), Tobelo (eighteenthnineteenth centuries in Maluku), and Lanun, Balangingi and Mangindanao in the Philippines. The Tobelo pirates were particularly notorious for disturbing the peace on the islands of the eastern archipelago. The Kaledupa and Liya forts not only provided hilltop locations well away from any direct pirate attack, but also enabled the inhabitants to observe the approach and defend themselves from unwelcome interests. In addition, the Wakatobi people are renowned for their skills in martial arts, which they like to show off wherever their boats are at anchor (Hamid 2007:77). These skills may well derive from the Wakatobi Islanders' particular need for selfdefence, especially during the heyday of the Wakatobi forts from the seventeenth century, when the Islamic kingdoms of Goa and Buton vied for political and commercial superiority against the rival imperial ambitions of Portuguese and Dutch trading interests (see Baker 2012; Chapter 6, this volume). 


\section{Conclusions}

The Wakatobi Islands are rich with ancient cultural relics, especially the relatively massive stone fortifications established as centres of settlement and defence in the island chain. In addition to Fort Kaledupa and Fort Liya, described here, there are many other defensive forts on these islands, according to an initial inventory of sites undertaken by the local government. The development of these forts was triggered by the islands' strategic geographical location for maritime trade and their role as a colony (barata) of the kingdom of Buton, serving as the eastern frontline defensive post. The cultural heritage contained in Fort Kaledupa and Fort Liya, including Chinese porcelains and Vietnamese tradeware, show that the Wakatobi region was integrated into much wider networks of trade that spanned insular Southeast Asia with connections to global markets. Similarly, the existence of old mosques and ancient Islamic-style graveyards indicate that the forts were part of the sixteenth- and seventeenth-century wave of conversion and proselytisation of Islam across the islands, eastern Indonesia and the Papuan coast. Certainly, the strategic shipping and trading position of Wakatobi has encouraged its people to adapt to their maritime environment, making them bold and brave seafarers with a strong maritime tradition as a key characteristic of their shared cultural identity.

\section{References}

Abubakar, L.O. 1999a. Armada penjaga keamanan pantai Kesultanan Buton. Majalah Budaya Buton (Wolio Molagi) 1:7-8.

Abubakar, L.O. 1999b. Pemahaman tentang sejarah yang bernama Wolio-Buton. Majalah Budaya Buton (Wolio Molagi) 1:37-40.

Andaya, L.Y. 1991. Local trade networks in Maluku in the sixteenth, seventeenth and eighteenth centuries. Cakalele: Maluku Research Journal 2(2):71-96.

Baker, B. 2012. Indigenous-driven mission: Reconstructing religious change in sixteenth century Maluku. Unpublished PhD thesis. The Australian National University, Canberra.

Donohue, M. 1999. A grammar of Tukang Besi. Mouton, Berlin.

Hamid, A.R. 2007. Pelayaran perahu dan DI/TII di perairan Kabaena-Sulawesi Tenggara, 1953-1965. Lensa Budaya (Jurnal llmu-ttmu Budaya) 2(1):85-104.

Joshua Project 2020. Bonerate in Indonesia. joshuaproject.net/people_groups/10933/ID. Accessed 20 February 2020.

Nontji, A. 1987. Laut Nusantara. Djambatan, Jakarta.

Reid, A. 1992. Asia Tenggara dalam kurun niaga 1450-1680. Volume 1. Yayasan Obor Indonesia, Jakarta.

Rosmawati 2018. The roles of the Liya and Kaledupa forts at Wakatobi as defensive forts of the Buton Kingdom. In M.R. Abdul Wahab, R.M.A. Zakaria, M. Hadrawi and Z. Ramli (eds), Selected topics on archaeology, history and culture in the Malay world, pp. 55-72. Springer, Singapore. doi.org/10.1007/ 978-981-10-5669-7_5.

Wikipedia 2020. Wakatobi Regency. en.wikipedia.org/wiki/Wakatobi_Regency Accessed 25 March 2020. 
This text is taken from Forts and Fortification in Wallacea: Archaeological and Ethnohistoric Investigations, edited by Sue O'Connor, Andrew McWilliam and Sally Brockwell, published 2020 by ANU Press, The Australian National University, Canberra, Australia.

doi.org/10.22459/TA53.2020.09 